\title{
Health and socioeconomic well-being of young people living with HIV in Zambia: Evaluating the ZAMFAM Project
}

Project SOAR

Follow this and additional works at: https://knowledgecommons.popcouncil.org/departments_sbsr-hiv

Part of the Demography, Population, and Ecology Commons, Family, Life Course, and Society Commons, International Public Health Commons, and the Maternal and Child Health Commons How does access to this work benefit you? Let us know!

\section{Recommended Citation}

Project SOAR. 2018. "Health and socioeconomic well-being of young people living with HIV in Zambia: Evaluating the ZAMFAM Project," Project SOAR Results Brief. Lusaka: Population Council. 


\section{Health and Socioeconomic Well-being of Young People Living with HIV in Zambia}

\section{Evaluating the ZAMFAM Project}

The U. S. Agency for International Development (USAID) and U. S. President's Emergency Plan for AIDS Relief (PEPFAR) are supporting the Zambia Family (ZAMFAM) project to strengthen comprehensive, integrated service delivery and support to children living with, affected by, or vulnerable to HIV/AIDS in the Lusaka, Copperbelt, Southern, and Central Provinces of Zambia. The goal of the project is to improve the care and resilience of orphaned and other vulnerable children (OVC), young people living with HIV (YPLHIV), and their households. ZAMFAM seeks to build the capacity of families and primary caregivers and provide childand family-focused services, including communitybased child welfare systems. The project is being implemented in the Southern and Central Provinces by Development Aid from People to People (DAPP) and in the Copperbelt and Lusaka Provinces by Expanded Church Response (ECR).

Project SOAR is conducting a three-year prospective cohort study of YPLHIV and their primary caregivers/ guardians in Central Province where DAPP is implementing the ZAMFAM project, and in Eastern Province where there are no ongoing ZAMFAM activities for comparison. ${ }^{1}$

\section{ABOUT THE STUDY}

The cohort study aims to: 1) Document key child and household well-being indicators among a cohort of YPLHIV and their households; 2) Assess the impact of ZAMFAM on the well-being of YPLHIV beneficiaries and their households, and 3) Assess the impact of ZAMFAM on utilization of care and treatment services among YPLHIV and their households.

${ }^{1}$ See projsoar.org/our-activities/zambia-zamfam/ for more information and resources on SOAR research related to the ZAMFAM Project.

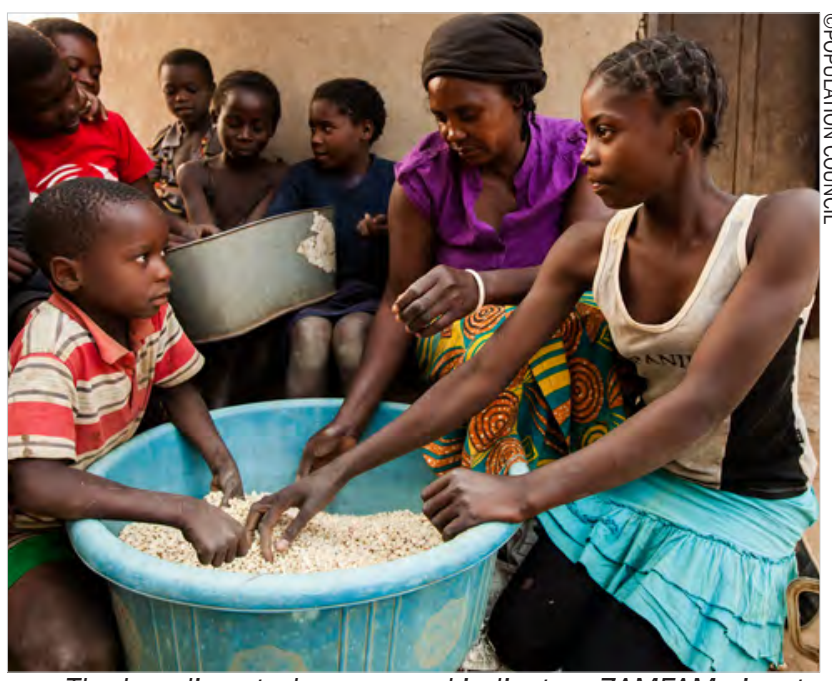

The baseline study measured indicators ZAMFAM aims to improve including health, food security, and schooling.

During the period from July to October 2017, we collected information on a total of 544 YPLHIV, aged 5-17 years, and the same number of caregivers/ guardians. Both sets of participants were divided equally across the two provinces. Only one child and her/his primary caregiver/guardian was selected per household. After providing informed consent, the primary caregivers/guardians were interviewed on mainly household indicators, but they also provided detailed information on the YPLHIV, aged 5-9 years, selected and recruited into the study. For YPLHIV 10-17 years of age, an interview was conducted directly with the child, after obtaining permission from the primary caregiver/guardian and the child.

The information collected in the study focused on key thematic areas that ZAMFAM aims to improve, including health and nutrition, food security, shelter, schooling, child protection, psychosocial status, and HIV testing and treatment. This research brief highlights some of the key baseline indicators of health and socioeconomic well-being of YPLHIV in the study sites. 


\section{WHO ARE THE STUDY SUBJECTS?}

\begin{tabular}{|c|c|c|}
\hline $\begin{array}{l}\text { Caregivers } \\
(n=544)\end{array}$ & $\begin{array}{ll}\text { YLPHIV } \\
5-9 \text { years old } \\
(n=225)\end{array}$ & YPLHIV $\begin{array}{l}\text { YPLIV years old } \\
10-17 \text { y } \\
(n=319)\end{array}$ \\
\hline $88 \%$ female & $52 \%$ female & $63 \%$ female \\
\hline Median age: 43 years & Median age: 7 years & Median age: 13 years \\
\hline $\begin{array}{l}\text { Marital status: } 54 \% \text { married or } \\
\text { in union, } 27 \% \text { widowed }\end{array}$ & $\begin{array}{l}\text { Enrolled in school (ages } 7-9 * \text { ): } \\
75 \% \text { females, } 59 \% \text { males }\end{array}$ & $\begin{array}{l}\text { Enrolled in school: } \\
77 \% \text { females, } 87 \% \text { males }\end{array}$ \\
\hline & *Children in Zambia start school at age 7. & \\
\hline
\end{tabular}

\section{KEY FINDINGS}

\section{Health indicators}

- About a third of younger (5-9 years) and older (10-17 years) YPLHIV in both study areas were too sick to participate in daily activities in the past two weeks (Figure 1). Among the older participants in Central Province, illness prevented more males than females from participating in activities (41 percent vs. 30 percent), although this difference was not statistically significant.

- Depending on study site and age group, between 26 and 31 percent of YPLHIV have not been tested for CD4 count in the past six months (Figure 2). There were no differences between males and females.

- About half of younger (5-9 years) and older (10-17 years) participants in the study areas have not been tested for viral load in the past six months (Figure 3). In Eastern Province, a greater proportion of younger boys than younger girls have been tested for viral load (59 percent vs. 44 percent). However, it was the opposite for older boys in Central Province compared to older girls (45 percent vs. 55 percent). The differences between males and females were not statistically significant.

- Although almost all of the younger (5-9 years) and older (10-17 years) participants were retained in care for the past 12 months (Figure 4), between 3 and 20 percent inconsistently took their medication in the past one month, depending on study site and age group (Figure 5). Retention in care and ART adherence were similar for males and females within the two age groups in Central Province. Although not statistically significant, there were notable differences between younger and older children in Eastern Province. In addition, more older children in Eastern Province were not consistently taking ART compared to their peers in Central Province, but the difference was not statistically significant.

- High proportions of YPLHIV had not received psychosocial support from a home visitor or social worker in the past six months:

- A much greater proportion of younger children (5-9 years) in Eastern Province (91 percent) had not received psychosocial support than in Central Province (57 percent).

- Among older children (10-17 years), more boys in Central Province had not received psychosocial support compared to girls (67 percent vs. 56 percent) while in Eastern Province, more girls than boys reported not having received support (90 percent vs. 83 percent). These differences however, were not statistically significant. 

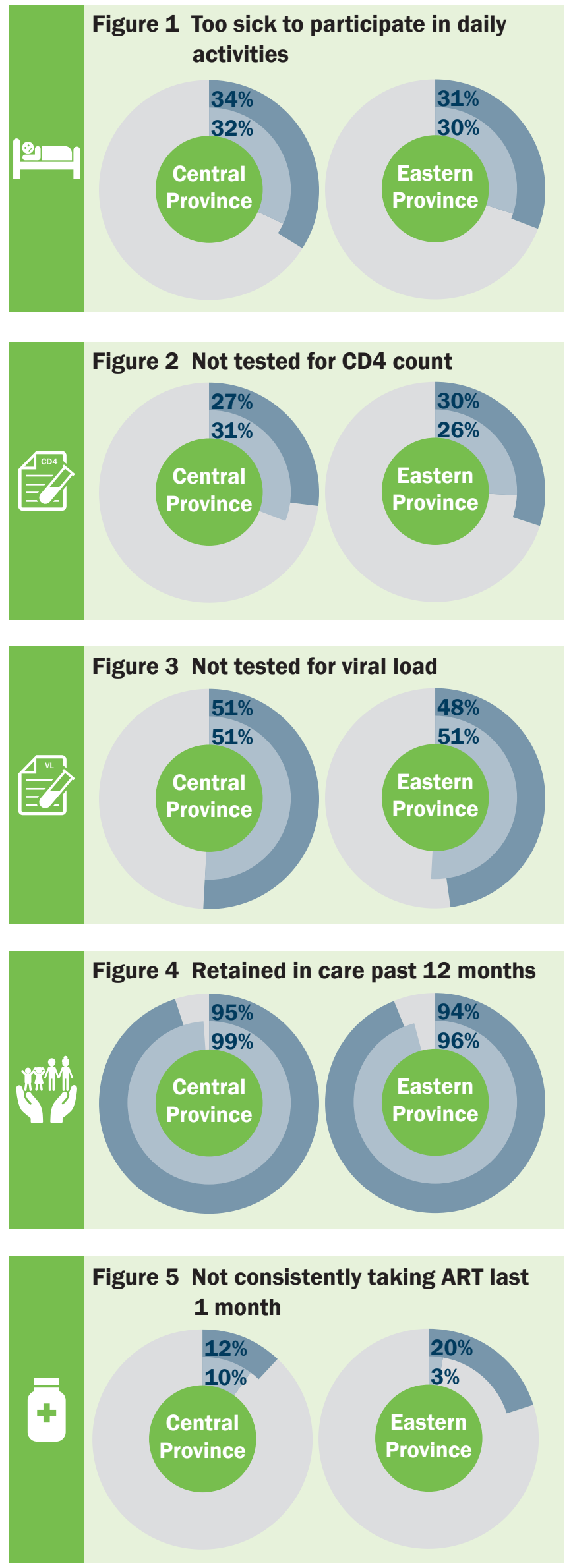

\section{Socioeconomic well-being indicators}

- Among the children enrolled in school, many had challenges with school attendance, and for the younger students in particular, grade progression (Table 1).

- Depending on the study site and age group, between 8 and 18 percent of YPLHIV lacked food for a whole day and night. Almost twice as many children went to bed hungry due to lack of enough food in the past four weeks (Table 1).

- A substantial proportion (between 20 and 58 percent) of YPLHIV lived in households that could not pay on their own for unexpected expenses, could not access money from other sources, or lacked enough food at least once in the past four weeks (Table 2, next page).

- Between 14 and 22 percent of YPLHIV lived in households where caregivers supported harsh physical punishment either at school or at home (Table 2, next page).

- Majority of caregivers lacked comprehensive knowledge about HIV/AIDS (51 percent in Central and 61 percent in Eastern Province).

Table 1 Indicators of socioeconomic well-being (\%)

\begin{tabular}{|lcc|cc|}
\hline & \multicolumn{2}{c|}{ Central } & \multicolumn{2}{c|}{ Eastern } \\
\hline $\begin{array}{l}\text { Indicator } \\
\text { Schooling } \\
\quad \text { Missed school }\end{array}$ & 46 & 32 & 36 & 28 \\
$\begin{array}{l}\text { at least once } \\
\text { last week* }\end{array}$ & & & & \\
$\begin{array}{l}\text { Did not progress } \\
\text { last school } \\
\text { year** }\end{array}$ & 23 & 3 & 23 & 9 \\
$\begin{array}{l}\text { Food intake } \\
\text { Lacked food for } \\
\text { a whole day and } \\
\text { night in the past }\end{array}$ & 18 & 17 & 12 & 8 \\
4 weeks & & & & \\
$\begin{array}{l}\text { Slept hungry at } \\
\text { night in the past }\end{array}$ & 37 & 37 & 22 & 14 \\
4 weeks & & & \\
\hline
\end{tabular}

*Younger age group data is for YPLHIV 7-9 years old, because children in Zambia start school at age 7.

**Younger age group data is for YLPHIV 8-9 years old. 
Table 2 Indicators of socioeconomic well-being: household environment (\%)

\begin{tabular}{|c|c|c|c|}
\hline & & $\begin{array}{l}\text { Central } \\
\text { Province }\end{array}$ & $\begin{array}{l}\text { Eastern } \\
\text { Province }\end{array}$ \\
\hline & $\begin{array}{l}\text { Caregiver supported } \\
\text { harsh punishment at: } \\
\text { Home } \\
\text { School }\end{array}$ & $\begin{array}{l}22 \\
15\end{array}$ & $\begin{array}{l}16 \\
14\end{array}$ \\
\hline sss/ & $\begin{array}{l}\text { No food in the } \\
\text { household at least } \\
\text { once in the last } \\
4 \text { weeks }\end{array}$ & 53 & 37 \\
\hline $\mathrm{K}$ & $\begin{array}{l}\text { For unexpected expenses, } \\
\text { households could not: } \\
\text { Pay on their own } \\
\text { Access money }\end{array}$ & $\begin{array}{l}\text { s, } \\
58 \\
47\end{array}$ & $\begin{array}{l}20 \\
55\end{array}$ \\
\hline
\end{tabular}

- About half of caregivers who were married or in union reported joint decision-making regarding how money earned is spent (43 percent in Central and 51 percent in Eastern Province).

- Most caregivers had someone to assist with household chores if they were sick (85 percent in Central and 89 percent in Eastern Province).

\section{RECOMMENDATIONS}

The key findings of health and socioeconomic wellbeing among YPLHIV participating in the baseline study suggest a need for the following programmatic actions:

- Strengthen caregiver capacity to provide for the health and well-being of YPLHIV and their households, including through improved linkages to health facilities.

- Strengthen community outreach activities by community health workers and counsellors to improve psychosocial and health support to
YPLHIV and their households, particularly in supporting YPLHIV when they are sick and in adhering to HIV medication.

- Sensitize caregivers and community health workers to ensure that YPLHIV under their care get CD4 count or viral load tests, as part of monitoring their health and treatment uptake.

- Enhance the capacity of caregivers to recognize symptoms of illnesses among YPLHIV, and seek timely care at appropriate places based on the nature of illness.

- Bolster knowledge on HIV care and treatment among primary caregivers and children.

- Strengthen support to YPLHIV who face healthrelated or other barriers in enrolling or attending school. This is particularly important for younger children who are more prone to experience school interruptions than older children.

- Strengthen strategies in the communities to improve household food security and household income, such as village banking and distribution of farm inputs to vulnerable households.

\section{NEXT STEPS}

Project SOAR is conducting further analysis of the baseline data to inform a more detailed description of health and socioeconomic well-being of YPLHIV in the study areas. In addition, Project SOAR will conduct interviews with the same study participants at 12, 24, and 36 months following the baseline interview to track progress in the outcomes for ZAMFAM beneficiary households compared to households where there are no program activities.

Suggested citation: Project SOAR. 2018. "Health and socioeconomic well-being of young people living with HIV in Zambia: Evaluating the ZAMFAM Project," Project SOAR Results Brief. Lusaka: Population Council.
Project SOAR is a five-year (September 2014-September 2019) cooperative agreement funded by the President's Emergency Plan for AIDS Relief and the U. S. Agency for International Development (Agreement No. AIDOAA-A-14-00060). SOAR is able to accept funding from all USAID accounts.

Population Council leads the Project SOAR consortium in collaboration with Avenir Health, Elizabeth Glaser Pediatric AIDS Foundation, the Johns Hopkins University, Palladium, and The University of North Carolina at Chapel Hill.
Project SOAR/Population Council 4301 Connecticut Avenue, NW, Suite 280 Washington, DC 20008

Tel: +1 2022379400

e-mail: ProjectSOAR@popcouncil.org projsoar.org

(อPopulation Council, February 2018 